\title{
Sistem Kendali Pengasutan Genset Portabel Dari Jarak Jauh Tanpa Kabel
}

\section{Wireless Remote Control System for Portable Home Generator}

\author{
Budhi Anto \\ Jurusan Teknik Elektro - Universitas Riau, Pekanbaru \\ Email:budhianto.ur@gmail.com
}

\begin{abstract}
Due to poisonous carbon monoxide (CO) emissions, portable home generator must be placed outdoor and not near doors, windows or air ventilations. This installation requirement may suggest the position of portable home generator to be far away from its transfer switch. Thus, a wireless remote control system for starting and stopping the generator is required as the operator might not need to be at site to start and stop the engine. An attempt to build a wireless remote control system that suited with portable gasoline generator was conducted in this research. The developed system consists of a remote controller unit in a hand-held size and the actuator unit that electrically connected with the controlled generator. Remote controller communicates with actuator unit in simplex mode using radio frequency of 433,92 MHz ISM band. The system has been implemented to start and stop remotely the YMW4500XE YAMAWA portable gasoline generator and the generator can be controlled up to 70 meters and also the generator installed inside three-storey building can be controlled from inside and outside building.
\end{abstract}

Keywords: wireless remote control system, simplex communication, portable home generator

\begin{abstract}
Abstrak
Karena menghasilkan emisi gas karbonmonoksida (CO) yang bersifat racun, genset portabel harus diletakkan di luar ruangan dan tidak di dekat pintu, jendela atau ventilasi udara. Kondisi ini menyebabkan posisi genset portabel berjauhan dengan saklar pemindahnya. Oleh karena itu suatu sistem kendali pengasutan dari jarak jauh tanpa kabel diperlukan untuk mempermudah operator dalam mengoperasikan genset portabelnya, sehingga dia tidak perlu berada di dekat genset untuk menyalakan atau memadamkan gensetnya. Dalam penelitian ini telah diupayakan untuk membuat sistem kendali pengasutan genset portabel dari jarak jauh tanpa kabel yang dapat dipasangkan pada genset portabel berbahan bakar premium. Sistem yang dibangun terdiri atas unit pengendali jarak jauh yang berukuran dapat digenggam dan unit aktuator yang secara permanen terhubung secara listrik dengan genset yang dikendalikan. Komunikasi antara unit pengendali jarak jauh dan unit aktuator terjadi secara simpleks menggunakan gelombang radio pita ISM pada frekuensi 433,92 MHz. Sistem yang dibuat telah diimplementasikan untuk menyalakan dan memadamkan genset portabel YMW4500XE merk YAMAWA dan genset tersebut dapat dikendalikan sampai jarak 70 meter dan juga genset yang berada di dalam bangunan berlantai tiga dapat dikendalikan dari dalam dan luar bangunan.
\end{abstract}

Kata kunci: sistem kendali jarak jauh tanpa-kabel, komunikasi simpleks, genset portabel

\section{Pendahuluan}

Tingkat pertumbuhan konsumsi listrik yang tinggi dan tidak diiringi dengan penambahan unit-unit pembangkit dan penguatan sistem kelistrikan menyebabkan perusahaan pengelola sistem kelistrikan atau perusahaan utilitas listrik seperti PLN memutus aliran listrik ke titik beban-titik beban tertentu dalam rangka mempertahankan

Received: 30 Nov 2015; Revised: 06 Juni 2016; Accepted: 07 Juni 2016; Published online: 21 Nov 2016 @2016 INKOM 2016/16-NO443 DOI: http://dx.doi.org/10.14203/j.inkom.443 kualitas tenaga listrik yang dihasilkannya. Selain itu pemadaman listrik dapat juga disebabkan oleh faktor eksternal pengelolaan sistem kelistrikan seperti gangguan cuaca (petir dan badai) dan bencana alam lainnya. Dapat dikatakan terputusnya pasokan listrik dari jaringan utilitas merupakan hal yang lazim terjadi beberapa kali dalam setahun dengan durasi pemadaman yang tidak pasti. Kondisi ini memaksa masyarakat untuk memasang sumber tenaga sekunder misalnya unit generating set (genset) untuk mencatu peralatanperalatan listriknya sewaktu pasokan listrik dari jaringan utilitas terputus. 
Genset pada hakikatnya adalah peralatan mesin yang terdiri atas generator listrik yang dikopel dengan jentera (engine) sebagai penggeraknya. Generator listrik berfungsi mengubah kerja mekanik yang dilakukan oleh jentera menjadi tenaga listrik. Terdapat beberapa jentera yang digunakan untuk memutar generator, yaitu menggunakan turbin gas, menggunakan turbin uap atau menggunakan jentera torak (reciprocating engine/piston engine). Bahan bakar jentera dapat menggunakan premium, solar ataupun gas.

Genset dapat dikelompokkan atas 2 jenis, yaitu genset stasioner (stationary genset) dan genset portabel (portable genset). Unit genset stasioner dipasang secara permanen pada suatu lokasi dengan pondasi yang dirancang untuk memikul berat genset tersebut. Kapasitas daya genset stasioner besar, biasanya diatas $10 \mathrm{kVA}$. Unit genset portabel dapat dipindah-pindah dan biasanya dilengkapi dengan roda. Kapasitas daya genset portabel biasanya dibawah $10 \mathrm{kVA}$.

Pada umumnya, rumah tangga dan usaha ekonomi skala mikro/kecil di Indonesia menggunakan genset portabel sebagai sumber tenaga sekundernya. Kapasitas daya genset portabel bervariasi antara $1 \mathrm{kVA}$ sampai dengan $10 \mathrm{kVA}$, dengan sistem tegangan 220 volt 1 fasa, 2 kawat. Jentera yang digunakan pada umumnya adalah jentera torak dengan bahan bakar premium dan ada juga dengan bahan bakar solar.

Genset portabel menghasilkan gas karbon monoksida (CO) yang bersifat racun bagi tubuh manusia [1]. Penelitian yang dilakukan oleh National Institute of Standard and Technology (NIST), suatu badan di bawah Departemen Perdagangan Amerika Serikat, menyatakan bahwa terdapat 4000 orang Amerika Serikat dimasukkan ke rumah sakit setiap tahun karena keracunan gas CO yang dihasilkan oleh genset portabel dan terdapat 500 kasus kematian karena sebab tersebut sejak tahun 2005. Keracunan gas CO disebabkan oleh genset portabel dipasang di dalam ruangan atau di dekat saluran ventilasi, di dekat pintu atau di dekat jendela. Penyebab lainnya adalah tingginya emisi gas $\mathrm{CO}$ oleh genset portabel yang biasa dijual [2]. Sebagai gambaran, batas berbahaya dari paparan gas $\mathrm{CO}$ bagi manusia adalah 35 ppm selama 10 jam [3]. Menurut penelitian yang dilakukan oleh Persily et.al, untuk genset portabel yang terpasang di dalam rumah atau di dalam garasi dekat rumah, batas emisi gas CO yang membahayakan bagi manusia adalah 27 gram tiap jam selama 18 jam terus-menerus [2]. Padahal genset portabel yang dipasarkan saat ini pada umumnya menghasilkan emisi gas $\mathrm{CO}$ sebesar 500 - 4000 gram/jam [4]. Oleh karena itu NIST telah melakukan tindakan pencegahan dengan menyarankan pemasangan stiker tanda peringatan tentang cara pemasangan genset portabel yang aman pada setiap genset portabel yang dijual di Amerika Serikat [5]. Tindakan pencegahan lainnya adalah usulan pembuatan genset portabel dengan tingkat emisi gas $\mathrm{CO}$ yang rendah [5].

Kasus keracunan gas $\mathrm{CO}$ oleh penggunaan genset portabel di Indonesia cukup besar seperti yang diberitakan pada media lokal maupun nasional [6-7], tetapi belum ada data statistik untuk hal tersebut.

Untuk menghindari keracunan gas $\mathrm{CO}$, genset portabel harus dipasang di tempat terbuka dan tidak di dekat pintu, di dekat jendela atau di dekat saluran ventilasi. Mengikuti instruksi pemasangan yang aman tersebut, maka posisi genset portabel akan berada relatif jauh dari saklar pemindahnya. Untuk mempermudah pengoperasian genset portabel, dalam penelitian ini telah diupayakan untuk membuat teknik baru pengendalian genset portabel yaitu sistem kendali pengasutan genset portabel dari jarak jauh tanpa kabel, sehingga operator genset tidak perlu repot berada dekat genset untuk menyalakan atau memadamkan gensetnya.

Sistem kendali jarak jauh tanpa kabel lebih menguntungkan daripada yang menggunakan kabel, mengingat peralatan yang dikendalikan (genset portabel) bersifat dapat dipindah-pindah dan juga posisi operator (penghuni rumah atau bangunan) dinamis. Sebagai ilustrasi, pada malam hari sewaktu sedang tidur tiba-tiba listrik padam dan seseorang harus menyalakan genset yang letaknya jauh dari kamar tidur. Ini tentu tidak akan merepotkan apabila di dekatnya ada alat pengendali jarak-jauh.

Beberapa penelitian yang berkaitan dengan pengendalian atau pemantauan kondisi genset dari jarak-jauh telah dilakukan oleh beberapa peneliti. Adoghe telah mengusulkan suatu sistem pemantauan dan pengendalian genset dari jarak jauh berbasis 2 unit komputer yang berkomunikasi secara serial communication [8]. Komputer pertama berada di dekat genset dan terhubung padanya melalui mikrokontroler PIC16F877. Mikrokontroler ini berfungsi memantau kondisi genset seperti jumlah bahan bakar, oli pelumas dan kondisi baterai serta mengendalikan on/off genset. Komputer kedua diletakkan di tempat jauh sebagai terminal untuk memantau kondisi genset dan terminal perintah on/off genset. Sidehabi telah 
mengusulkan suatu sistem untuk memantau kondisi genset dan kendali on/off dari jarak jauh berbasis website menggunakan modul arduino [9]. Boopathi et.al, telah membuat sistem pemantauan kondisi genset yang terpasang pada pabrik peleburan baja dari jarak jauh [10]. Mereka memantau temperatur mesin, jumlah bahan bakar dan level minyak pelumas genset secara terusmenerus. Apabila ketiga parameter tersebut melebihi batas, maka sistem akan mengirim tanda peringatan kepada petugas yang berwenang melalui jaringan GSM (global system for mobile communication) dalam bentuk pesan singkat (SMS). Sistem kendali-sistem kendali yang diusulkan diatas kurang cocok untuk penerapan di rumah tangga karena instalasi dan pengoperasiannya tidak praktis.

Sistem kendali pengasutan jarak jauh genset portabel telah dibuat oleh beberapa beberapa pabrikan genset portabel seperti Honda dan Yamaha [11], tetapi sistem tersebut hanya bisa digunakan untuk genset buatannya saja dan tipe tertentu saja.

Dalam penelitian ini, sistem kendali yang dibuat dapat digunakan pada sebarang genset portabel. Sistem kendali yang dibangun terdiri atas unit pengendali jarak jauh yang berukuran dapatdigenggam dan unit aktuator yang terhubung permanen secara listrik dengan genset yang dikendalikan. Komunikasi antar unit menggunakan gelombang radio, sehingga genset portabel dapat dikendalikan dari berbagai lokasi tanpa kendala kelurusan antara unit pengendali jarak jauh dengan unit aktuator. Sistem kendali yang dibangun diimplementasikan untuk mengasut genset portabel berbahan bakar premium.

\section{Rancangan sistem kendali}

Terdapat 2 metode untuk mengasut genset portabel, pertama, pengasutan menggunakan recoil dan yang kedua, pengasutan menggunakan dinamo starter. Genset portabel dengan pengasutan menggunakan dinamo starter selalu dilengkapi dengan baterai akumulator untuk menggerakkan dinamo starter. Dalam keadaan beroperasi, genset secara otomatis mengisi muatan baterai, sehingga baterai akan selalu mempunyai tenaga listrik untuk mengasut genset tersebut.

Genset portabel berbahan bakar premium dan genset portabel berbahan bakar solar diasut dengan cara yang berbeda. Genset berbahan bakar premium diasut dengan terlebih dahulu membuka kontak bypass sirkit kumparan pengapian (ignition coil) genset dan kemudian meng-energize solenoid untuk menutup sirkit dinamo starter. Solenoid di- energize selama beberapa detik sampai jentera menyala dan kemudian hubungan arus listrik ke solenoid dibuka sehingga sirkit dinamo starter terbuka. Pemadaman genset berbahan bakar premium dilakukan dengan menutup kontak bypass sirkit kumparan pengapian. Genset berbahan bakar solar diasut dengan terlebih dahulu meng-energize solenoid katup bahan bakar sehingga bahan bakar tersedia pada pompa bahan bakar, kemudian meng-energize solenoid untuk menutup sirkit dinamo starter. Pemadaman genset solar dilakukan dengan men-deenergize solenoid katup bahan bakar.

Sistem yang dibuat digunakan untuk mengendalikan genset portabel berbahan bakar premium merk Yamawa (Gambar 1). Diagram blok sistem kendali pengasutan genset portabel dari jarak jauh diperlihatkan pada Gambar 2. Sistem kendali secara garis besar terdiri atas 2 bagian yaitu unit pengendali jarak jauh dan unit aktuator. Kedua bagian tersebut berkomunikasi secara simpleks, unit pengendali jarak jauh sebagai pemancar sinyal gelombang radio dan unit aktuator sebagai penerima sinyal gelombang radio. Unit pengendali jarak jauh terdiri dari rangkaian enkoder yang dilengkapi dengan modulator RF dengan frekuensi sinyal pembawa 433,92 Mhz. Frekuensi 433,92 Mhz termasuk frekuensi pita ISM (industrial, scientific and medical) sehingga tidak memerlukan izin dari otoritas yang berwenang [12]. Unit enkoder berfungsi mengubah data posisi/status peralatan masukan yaitu tombol kendali ON, tombol kendali OFF dan tombol kendali IGNITION, menjadi format data serial yang akan ditransmisikan oleh modulator.

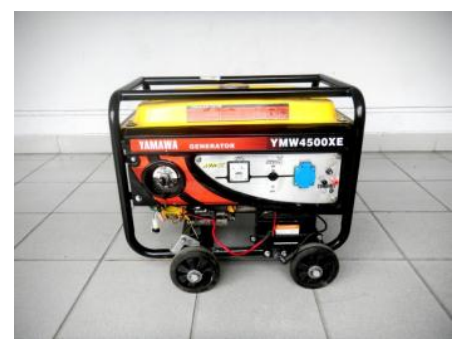

Gambar 1. Genset portabel YMW4500XE merk Yamawa

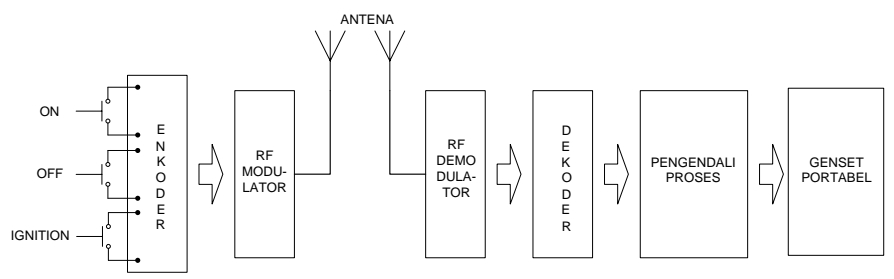

Gambar 2. Diagram blok sistem kendali pengasutan genset portabel dari jarak jauh 
Unit aktuator terdiri atas rangkaian demodulator RF beserta dekodernya dan pengendali proses. Baik modulator maupun demodulator bekerja pada frekuensi yang sama yaitu 433,92 Mhz. Rangkaian dekoder berfungsi mengubah data serial yang ditransmisikan oleh bagian pemancar menjadi data digital yang dapat diolah lebih lanjut oleh bagian pengendali proses. Agar unit pengendali jarak jauh dan unit aktuator dapat saling mengenali, pada enkoder dan dekoder terdapat kanal-kanal alamat yang dapat disetel sesuai kebutuhan. Setelan alamat pada enkoder harus sama dengan setelan alamat pada dekoder.

Bagian pengendali proses berfungsi mengendalikan proses on/off genset portabel. Bagian ini menggunakan rangkaian relai-relai elektromagnet. Proses kendali on/off genset portabel mempunyai 3 masukan digital yaitu status tombol ON, status tombol OFF dan status tombol IGNITION yang diperoleh dari unit pengendali jarak jauh melalui rangkaian dekoder dan 2 keluaran digital yang berupa 2 buah kontak untuk menyalakan dan memadamkan genset portabel. Kedua kontak relai-relai elektromagnet tersebut terhubung langsung dengan genset yang dikendalikan.

Genset portabel dirancang untuk dapat bekerja dengan operasi kendali lokal dan operasi kendali jarak jauh. Pada operasi kendali lokal, proses on/off genset portabel dikendalikan oleh kuncikontak (Gambar 3). Kunci kontak (key switch) mempunyai 3 posisi yaitu posisi OFF, posisi ON dan posisi IGNITION. Selain itu kunci kontak mempunyai 2 kontak yaitu kontak A yang merupakan kontak NC (normally closed) dan kontak B yang merupakan kontak NO (normally open). Pada posisi OFF, kontak A tertutup dan kontak B terbuka. Pada posisi ON, kontak A terbuka dan kontak B terbuka. Pada posisi IGNITION, kontak A terbuka dan kontak B tertutup. Untuk menyalakan genset portabel, posisi kunci-kontak dipindahkan dari posisi OFF ke posisi ON dan kemudian ke posisi IGNITION selama beberapa detik sampai genset menyala. Kemudian posisi kunci kontak dipindahkan dari posisi IGNITION ke posisi ON. Untuk memadamkan genset portabel, posisi kunci kontak dipindahkan dari posisi ON ke posisi OFF. Pada operasi kendali jarak jauh, peranan kunci kontak digantikan oleh kontak-kontak relai-relai elektromagnet yang terdapat pada bagian pengendali proses. Untuk itu diperlukan suatu mekanisme seleksi operasi kendali yang diim- plementasikan menggunakan rangkaian saklar pemilih sebagaimana diperlihatkan pada Gambar 4.

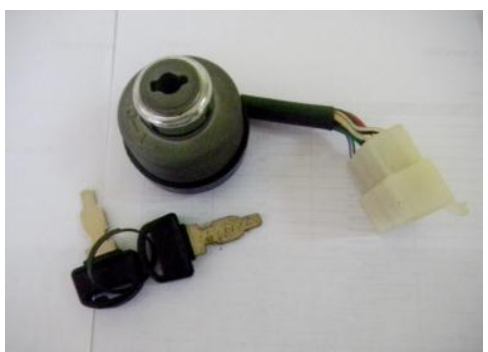

Gambar 3. Kunci-kontak genset portabel YMW4500XE Yamawa

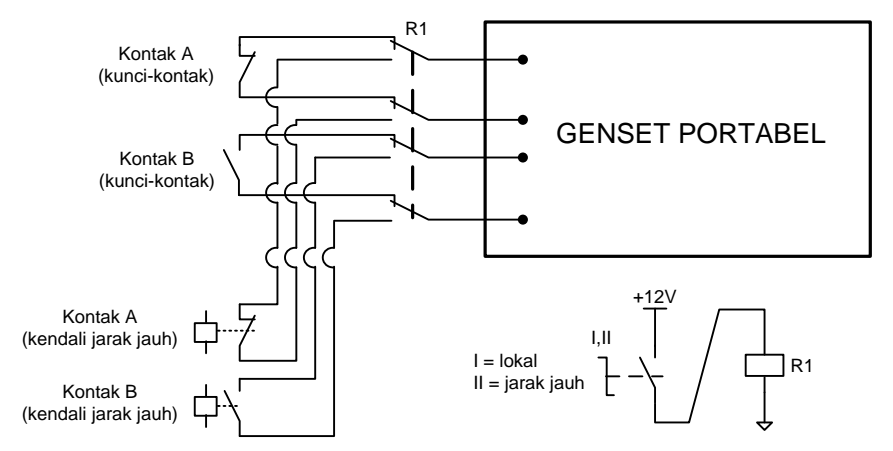

Gambar 4. Diagram pengawatan saklar pemilih untuk operasi kendali lokal dan operasi kendali jarakjauh

\section{Implementasi rancangan}

Realisasi sistem kendali pengasutan genset portabel dari jarak jauh tanpa kabel adalah sebagai berikut.

\subsection{Unit pengendali jarak jauh}

Unit pengendali jarak jauh terdiri atas enkoder data dan modulator RF. Sebagai enkoder digunakan rangkaian terintegrasi HT12E buatan Holtek Semiconductor dalam kemasan DIP 18 pin [13]. HT12E mempunyai 8 kanal untuk pengalamatan (ADDRESS) dan 4 kanal untuk data (DATA). Pengalamatan diperlukan untuk komunikasi antara bagian pemancar dan bagian penerima sehingga keduanya dapat saling mengenali. Penyetelan alamat pada unit enkoder dilakukan dengan memasang 8 (delapan) saklar mini dalam kemasan DIP 16 pin yang disambungkan ke kedelapan kanal ADDRESS. Setelan alamat pada unit enkoder pemancar harus sama dengan setelan alamat pada unit dekoder penerima. Selanjutnya tombol ON, tombol OFF dan tombol IGNITION untuk kendali jarak jauh genset portabel dihubungkan ke kanal-kanal DATA. 


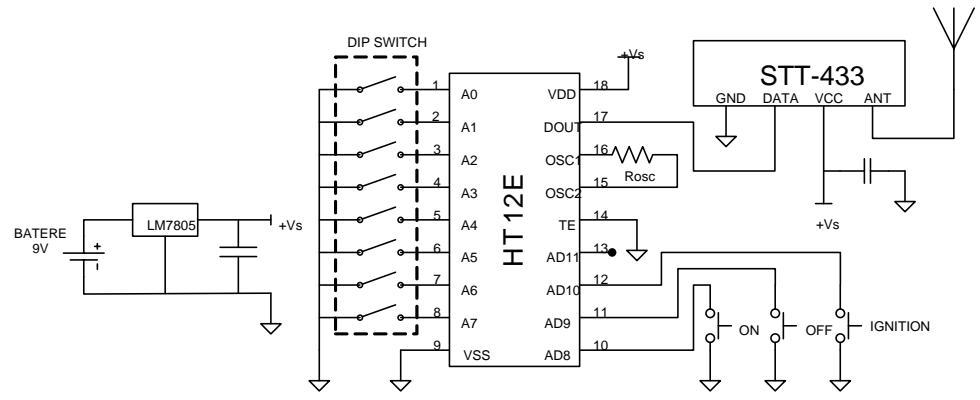

Gambar 5. Skematik rangkaian unit pengendali jarak jauh

Data serial keluaran HT12E kemudian ditransmisikan oleh modulator RF dalam bentuk rangkaian hibrid STT-433 buatan Sunrom Technologies. STT-433 adalah modulator digital jenis on-off keying (OOK) dengan frekuensi sinyal pembawa 433,92 Mhz [14]. Skematik rangkaian unit pengendali jarak jauh diperlihatkan pada Gambar 5. Keseluruhan rangkaian pemancar dicatu oleh baterai bertegangan 9 volt.

\subsection{Unit aktuator}

Unit aktuator terdiri atas bagian penerima sinyal gelombang RF, bagian pengendali proses dan bagian catu daya. Bagian penerima terdiri atas demodulator $\mathrm{RF}$, dekoder data dan rangkaian keluaran yang merupakan masukan untuk bagian pengendali proses. Sebagai demodulator RF digunakan rangkaian hibrid STR-433 yang merupakan pasangan STT-433. STR-433 menggunakan demodulator modulasi amplitudo jenis super-regenerative dan dilengkapi dengan rangkaian data slicer untuk mengubah sinyal keluaran demodulator menjadi sinyal yang kompatibel dengan peralatan-peralatan yang mempunyai masukan jenis CMOS/TTL [15]. Data serial keluaran STR-433 diolah oleh rangkaian dekoder data. Keluaran rangkaian dekoder adalah data digital untuk mengendalikan proses on/off genset portabel. Keluaran rangkaian dekoder menggerakkan 3 buah relai elektromagnet. Ketiga relai elektromagnet tersebut berkorelasi dengan ketiga tombol perintah yang terdapat pada unit pengendali jarak jauh. Kontak-kontak ketiga relai elektromagnet tersebut menjadi masukan bagi rangkaian pengendali proses.

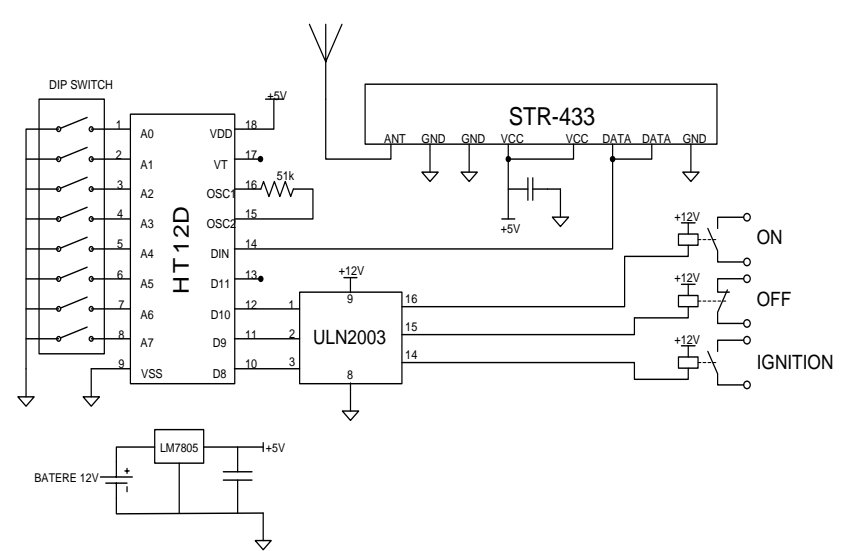

Gambar 6. Skematik rangkaian bagian penerima

Rangkaian terintegrasi HT12D buatan Holtek Semiconductor digunakan sebagai dekoder data [16]. HT12D merupakan pasangan HT12E. Seperti HT12E, HT12D mempunyai 8 kanal untuk pengalamatan (ADDRESS) dan 4 kanal untuk data (DATA). Setelan alamat pada HT12D harus sama dengan setelan alamat pada HT12E sehingga keduanya dapat saling mengenali. Selanjutnya 3 kanal DATA HT12D yang identik dengan 3 kanal DATA HT12E dihubungkan ke rangkaian penggerak relai ULN2003 untuk menggerakkan 3 relai keluaran. Kontak-kontak ketiga relai keluaran tersebut nantinya akan dihubungkan ke bagian pengendali proses untuk mengendalikan operasi on/off genset portabel. Skematik rangkaian penerima diperlihatkan pada Gambar 6 . Keseluruhan rangkaian penerima dicatu oleh regulator tegangan 5 volt yang mendapat pasokan tenaga listrik dari baterai 12 volt.

\subsection{Bagian pengendali proses}

Bagian pengendali proses menggunakan menggunakan rangkaian relai-relai elektromagnet. Masukan bagian pengendali proses berasal dari bagian penerima. Bagian pengendali proses menggunakan 3 relai elektromagnet yang digerakkan oleh tegangan searah 12 volt. Keluaran bagian pengendali proses dihubungkan ke sistem kelistrikan genset portabel. Skematik rangkaian pengendali proses diperlihatkan pada Gambar 7.

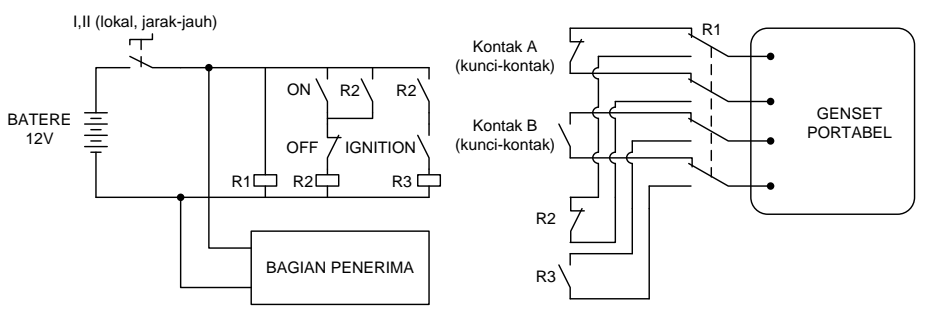

Gambar 7. Skematik rangkaian pengendali proses 


\subsection{Bagian catu daya}

Bagian catu daya terdiri atas baterai akumulator dan unit pengisi muatannya (battery charger). Baterai yang digunakan adalah dari jenis SLA (sealed lead acid) sehingga bebas perawatan. Unit pengisi muatan baterai menggunakan modus pengisian mengambang (float charging) dan dicatu oleh tegangan bolak-balik 220 volt yang berasal dari keluaran genset portabel atau dari instalasi listrik rumah. Skematik rangkaian catu daya diperlihatkan pada Gambar 8.

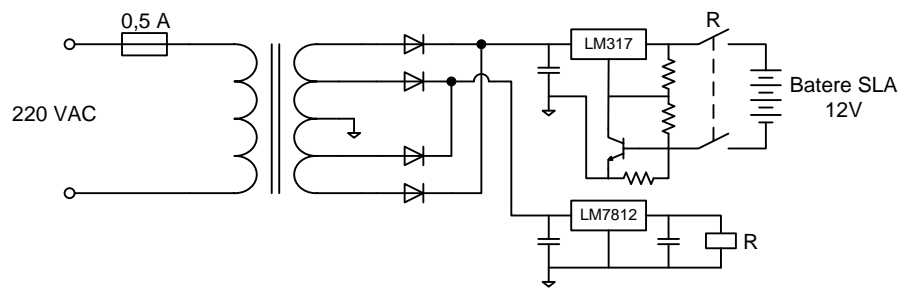

Gambar 8. Skematik rangkaian catu daya

\subsection{Perhitungan kemampuan jangkauan komunikasi sistem kendali jarak jauh}

Perhitungan kapasitas jangkauan sistem telekomunikasi sangat penting dilakukan sebagai dasar pertimbangan pemilihan modul pemancar dan modul penerimanya. Kapasitas jangkauan $(r)$ tersebut dapat dihitung menggunakan persamaan berikut [17],

$$
r=\frac{\lambda}{4 \pi 10^{\frac{a_{r}}{20}}}
$$

dengan $\lambda$ adalah panjang gelombang dalam satuan meter yang dihitung sesuai persamaan berikut,

$$
\lambda=\frac{c}{f}
$$

dengan $c$ adalah kecepatan rambat gelombang radio di ruang hampa yaitu $3 \times 10^{8} \mathrm{~m} /$ detik dan $f$ adalah frekuensi dalam satuan hertz.

Nilai $a_{r}$ dihitung sesuai persamaan berikut,

$$
a_{r}=L_{P}-L_{M}
$$

dengan $L_{P}$ adalah path loss yaitu redaman yang dialami oleh gelombang radio dalam perambatannya dari pemancar ke penerima dan $L_{M}$ adalah fade margin yaitu selisih antara intensitas medan elektromagnetik pada sisi penerima dengan sensitifitas penerima, yang harus disediakan untuk mengantisipasi efek fading [18]. Baik $L_{P}$ maupun $L_{M}$ masing-masing dalam satuan $\mathrm{dBm}$. Nilai $L_{P}$ dihitung sesuai persamaan berikut,

$$
L_{P}=P_{R}-P_{T}-\left(G_{T}+G_{R}\right)
$$

dengan $P_{R}$ adalah sensitifitas penerima, $P_{T}$ adalah daya yang dipancarkan oleh pemancar, $G_{T}$ adalah penguatan antena pemancar dan $G_{R}$ adalah penguatan antena penerima. Semua besaran diatas adalah dalam satuan $\mathrm{dBm}$.

Tabel 1. Faktor redaman bahan-bahan bangunan terhadap gelombang radio dengan frekuensi $434 \mathrm{MHz}$

\begin{tabular}{ll}
\hline \multicolumn{1}{c}{ Bahan bangunan } & Redaman \\
\hline Kaca & $2 \mathrm{dBm} /$ meter \\
Papan & $3 \mathrm{dBm} /$ meter \\
Pasangan bata & $32 \mathrm{dBm} /$ meter \\
Beton & $13 \mathrm{dBm} /$ meter \\
\hline
\end{tabular}

Perlu diketahui bahwa persamaan (3) di atas diperoleh dengan menganggap bahwa tidak terdapat penghalang antara pemancar dan penerima. Jika antara pemancar dan penerima terdapat penghalang seperti tembok, jendela dan lain-lain, maka faktor redaman $L_{A}$ harus dimasukkan ke persamaan (3) sehingga diperoleh persamaan berikut, $a_{r}=L_{P}-L_{M}-L_{A}$

Tabel 1 menampilkan redaman per satuan panjang dari berbagai bahan bangunan yang umum terhadap gelombang radio dengan frekuensi 434 $\mathrm{MHz}$ [20].

Sesuai datasheet modul pemancar dan modul penerima diperoleh data-data $f=433,92 \mathrm{MHz} ; P_{T}$ $=16 \mathrm{dBm} ; P_{R}=-105 \mathrm{dBm} ;$ Nilai $G_{T}$ dan $G_{R}$ disamping ditentukan oleh karakteristik antena juga dipengaruhi oleh kehilangan daya pada saluran transmisi yang menghubungkan antara modul pemancar atau modul penerima dengan antena-antenanya. Di sini diambil nilai $G_{T}=-20$ $\mathrm{dBm}$ dan $G_{R}=-8 \mathrm{dBm}$ [17]. Nilai minimal $L_{M}$ adalah $-15 \mathrm{dBm}$, di sini digunakan $L_{M}=-25 \mathrm{dBm}$ [19]. Dengan memasukkan nilai-nilai diatas ke dalam persamaan (4) diperoleh $L_{P}=-93 \mathrm{dBm}$. Dari persamaan (3) diperoleh $a_{r}=-68 \mathrm{dBm}$. Dari persamaan (2) diperoleh $\lambda=0,691 \mathrm{~m}$, dan dari persamaan (1) diperoleh kapasitas jangkauan sistem telekomunikasi sebesar 138,12 m. Kapasitas jangkauan ini mencukupi untuk aplikasi sistem kendali jarak jauh peralatan rumah tangga.

\section{Hasil dan pembahasan}

Sistem kendali pengasutan genset portabel dari jarak jauh telah dirakit seperti diperlihatkan pada Gambar 9, Gambar 10, Gambar 11, Gambar 12 dan Gambar 13. Sistem kendali kemudian diuji jangkauan fungsionalnya pada 2 kondisi operasi. Pada pengujian pertama, unit pengendali jarak jauh dan unit aktuator berada pada elevasi yang sama. Pada pengujian kedua, kedua unit tersebut berada pada elevasi yang berbeda. 

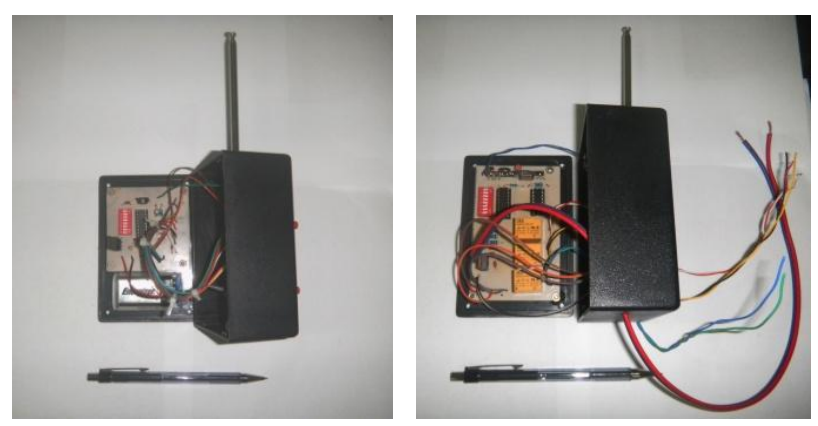

Gambar 9. Unit pengendali jarak jauh (kiri), bagian penerima (kanan)

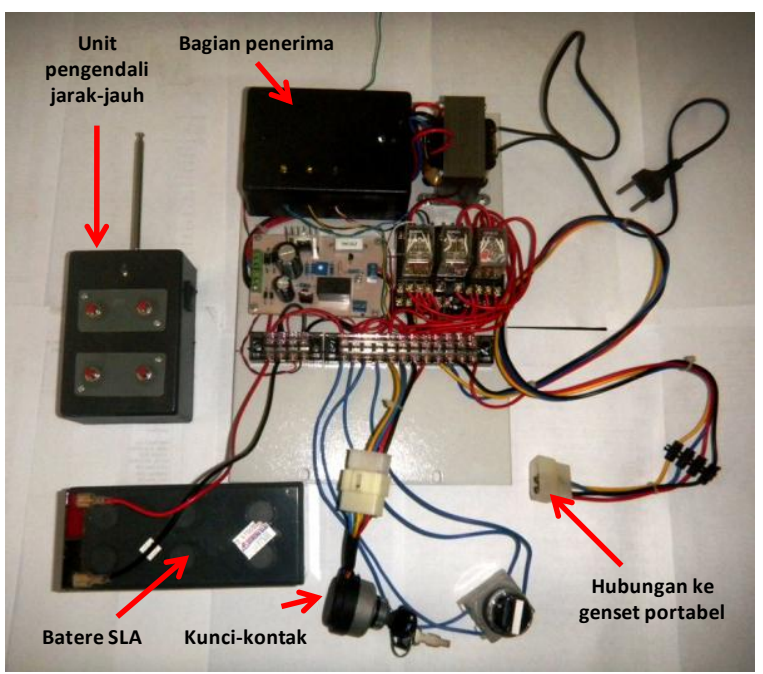

Gambar 10. Komponen-komponen sistem

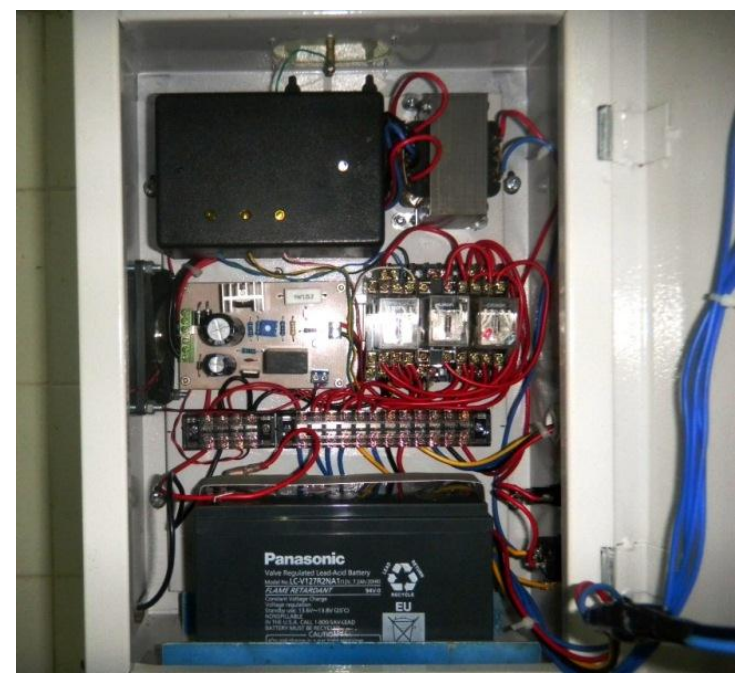

Gambar 11. Unit aktuator yang terakit dalam panel

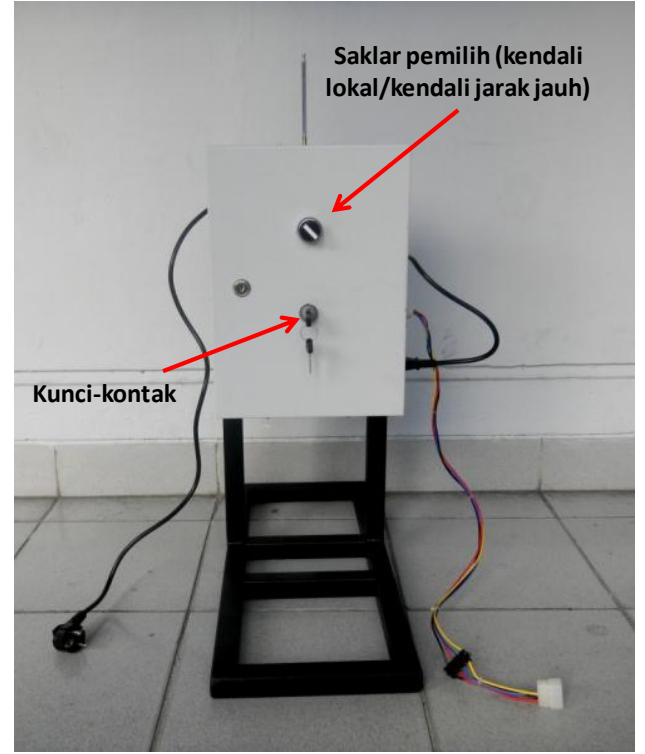

Gambar 12. Unit aktuator lengkap

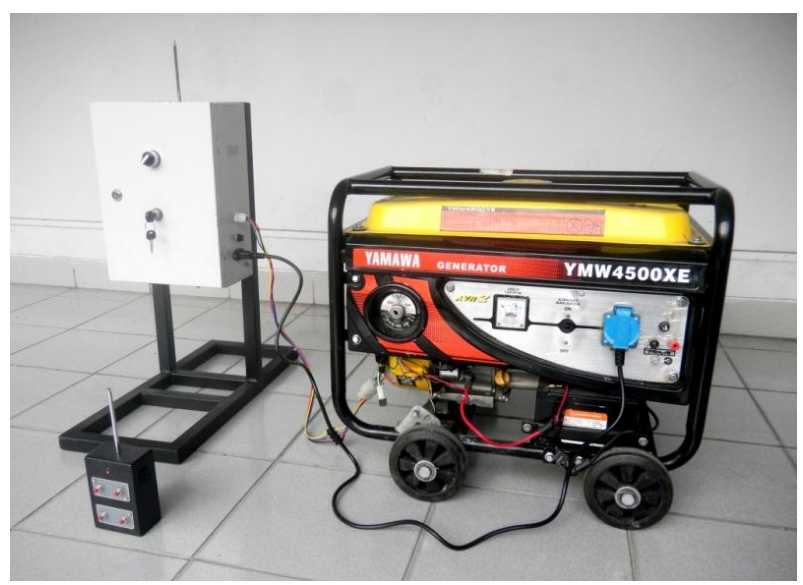

Gambar 13. Unit aktuator yang terhubung dengan genset portabel

Pada pengujian pertama, unit aktuator diletakkan di dalam ruangan (Laboratorium Elektronika Industri, Universitas Riau) dan unit pengendali jarak jauh berada di luar ruangan. Fungsional sistem kendali diamati dengan mengenergize dan men-deenergize kedua relai elektromagnet yang terdapat pada unit aktuator dari jarak jauh. Pengujian jangkauan fungsional dilakukan pada berbagai jarak sampai unit pengendali jarak jauh tidak dapat mengendalikan unit aktuator lagi. Diagram pengujian fungsional sistem kendali diperlihatkan pada Gambar 14. Hasil pengujian fungsional sistem kendali ditampilkan pada Tabel 2. 


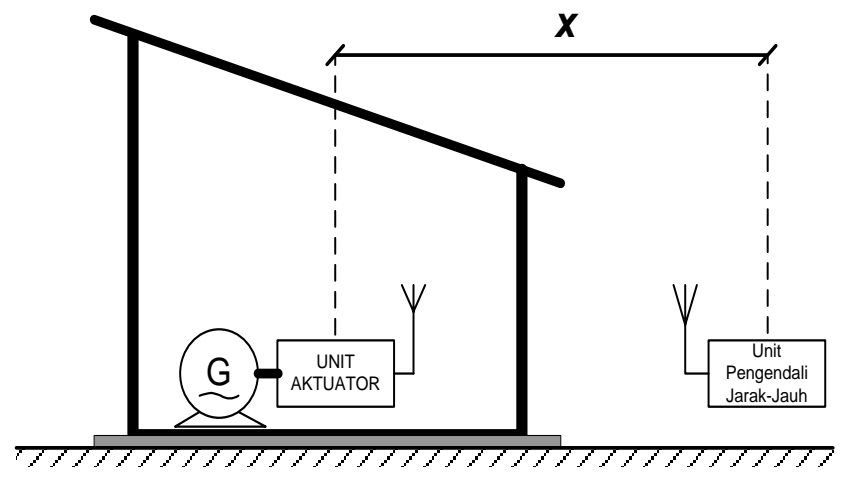

Gambar 14. Diagram pengujian fungsional sistem kendali jarak jauh, pemancar dan penerima pada elevasi yang sama

Tabel 2. Hasil pengujian fungsional sistem kendali, pemancar dan penerima pada elevasi sama

\begin{aligned} & \hline$x$ Fungsi kendali \\ & \hline $10 \mathrm{~m}$ Berfungsi \\ & $30 \mathrm{~m}$ Berfungsi \\ & $50 \mathrm{~m}$ Berfungsi \\ & $70 \mathrm{~m}$ Berfungsi \\ & $80 \mathrm{~m}$ Tidak berfungsi \\ & \hline\end{aligned}

Hasil pengujian pada Tabel 2 memperlihatkan bahwa unit aktuator masih dapat dikendalikan sampai jarak $70 \mathrm{~m}$. Angka ini lebih kecil dari pada kapasitas jangkauan sistem telekomunikasi sebesar 138,12 m. Hal ini disebabkan oleh adanya penghalang antara pemancar dan penerima yaitu dinding ruangan yang berupa pasangan batu bata setebal 12 $\mathrm{cm}$. Dari Tabel 1 diketahui bahwa dinding yang terbuat dari pasangan batu bata memberikan redaman sebesar $5 \mathrm{dBm} /$ meter terhadap gelombang radio dengan frekuensi 433,92 $\mathrm{MHz}$. Untuk dinding dengan pasangan batu bata setebal $12 \mathrm{~cm}$, maka $L_{A}=0,12$ meter $\times(-32 \mathrm{dBm} /$ meter $)=-3,84$ $\mathrm{dBm}$. Dengan memasukkan $L_{A}=-3,84 \mathrm{dBm}$ ke persamaan (5), maka diperoleh $a_{R}=-64,16 \mathrm{dBm}$ dan dari persamaan (2) dan persamaan (1) diperoleh jangkauan sistem telekomunikasi sebesar $88,77 \mathrm{~m}$. Nilai tersebut dekat dengan jangkauan fungsional sistem kendali berdasarkan hasil pengujian.

Pada pengujian kedua, unit aktuator diletakkan pada lantai 2 bangunan berlantai 3 (Gedung C Fakultas Teknik Universitas Riau) dan unit pengendali jarak jauh berada di beberapa posisi di dalam dan di luar bangunan. Pengujian kedua ini dilakukan dengan tujuan bahwa biasanya pada bangunan rumah-toko atau rumah-kantor (ruko dan rukan), genset portabel diletakkan di lantai atas atau atap bangunan, sehingga diharapkan genset tersebut dapat dikendalikan oleh operator yang berada di dalam bangunan. Diagram pengujian fungsional sistem kendali diperlihatkan pada Gambar 15. Hasil pengujian fungsional ditampilkan pada Tabel 3.

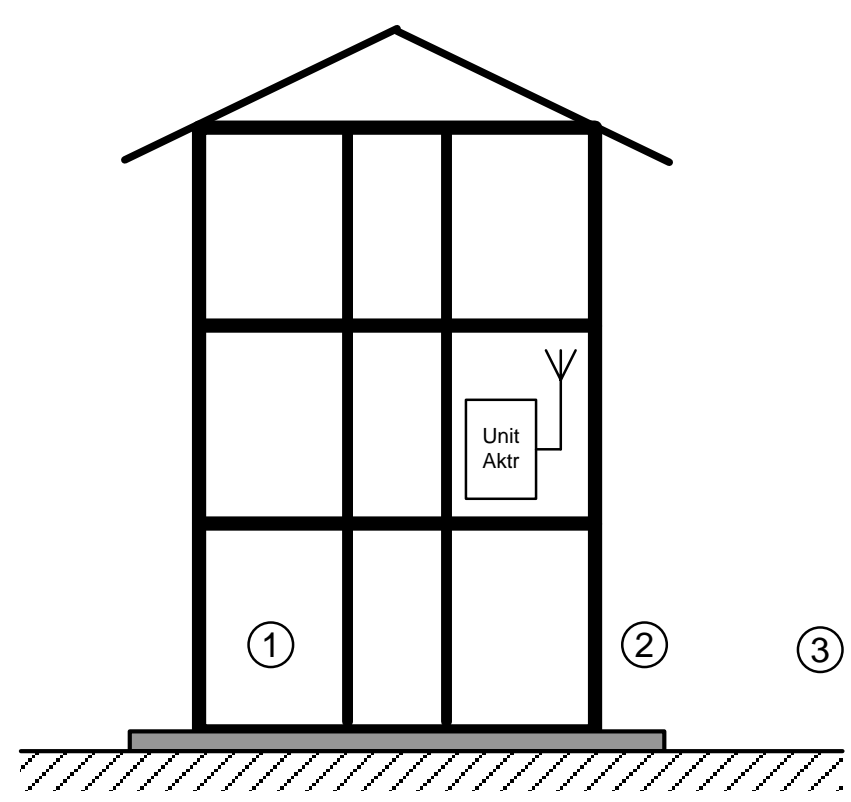

Gambar 15. Diagram pengujian fungsional sistem kendali, pemancar dan penerima pada elevasi yang berbeda

Tabel 3. Hasil pengujian fungsional sistem kendali, pemancar dan penerima pada elevasi berbeda

\begin{tabular}{cccc}
\hline Posisi & $\begin{array}{c}\text { Jarak dengan } \\
\text { penerima }\end{array}$ & $\begin{array}{c}\text { Fungsi } \\
\text { kendali }\end{array}$ & $\begin{array}{c}\text { Keterang- } \\
\text { an }\end{array}$ \\
\hline 1 & $12 \mathrm{~m}$ & Berfungsi & $\begin{array}{c}\text { Di dalam } \\
\text { bangunan } \\
\text { Di luar } \\
\text { bangunan } \\
\text { Di luar } \\
\text { bangunan }\end{array}$ \\
\hline
\end{tabular}

Hasil pengujian pada Tabel 3 memperlihatkan bahwa unit pengendali jarak jauh dapat mengendalikan unit aktuator yang berada di dalam bangunan berlantai 3 baik dari dalam maupun dari luar bangunan. Ketika unit aktuator diletakkan di lantai 2, dilihat dari posisi 1, gelombang radio mengalami redaman yang disebabkan oleh 2 dinding bangunan setebal $12 \mathrm{~cm}$ dan lantai beton setebal $20 \mathrm{~cm}$. Dari Tabel 1 gelombang radio mengalami redaman sebesar $(3,84 \mathrm{dBm}+3,84$ $\mathrm{dBm}+2,6 \mathrm{dBm})$ atau $10,28 \mathrm{dBm}$. Dengan menggunakan $L_{A}=-10,28 \mathrm{dBm}$ ke persamaan (5), maka diperoleh $a_{R}=-57,72 \mathrm{dBm}$ dan dari persamaan (2) dan persamaan (1) diperoleh jangkauan sistem telekomunikasi sebesar 42,29 m. Dengan demikian, pada posisi 1, jarak antara pemancar dan penerima sebenarnya dapat mencapai 42,29 m. 
Pada posisi 2 dan posisi 3, unit penerima berada di dalam bangunan dan unit pemancar berada di luar bangunan sehingga redaman terhadap gelombang radio hanya disebabkan oleh dinding pasangan bata setebal $12 \mathrm{~cm}$ yaitu sebesar 3,84 $\mathrm{dBm}$. Dengan menggunakan $L_{A}=-3,84 \mathrm{dBm}$ ke persamaan (5), maka diperoleh $a_{R}=-64,16 \mathrm{dBm}$. Dari persamaan (2) dan persamaan (1) diperoleh jangkauan sistem telekomunikasi sebesar $88,77 \mathrm{~m}$. Dengan demikian, unit aktuator yang berada di lantai 2 sebenarnya dapat dikendalikan dari luar bangunan sampai jarak $88,77 \mathrm{~m}$.

\section{Kesimpulan}

Sistem kendali pengasutan genset portabel dari jarak jauh menggunakan komunikasi frekuensi radio telah dibuat. Sistem kendali tersebut bekerja secara simpleks, dimana komunikasi berlangsung hanya satu arah yaitu dari unit pengendali jarak jauh ke unit aktuator. Hasil pengujian memperlihatkan bahwa genset portabel yang berada di dalam ruangan dapat dikendalikan sampai jarak 70 meter dan genset portabel yang berada di dalam bangunan berlantai 3 dapat dikendalikan dari dalam dan luar bangunan. Sistem kendali ini mempermudah kerja operator genset sehingga dia tidak perlu berada di dekat genset portabel untuk menghidupkan atau memadamkannya.

\section{Ucapan Terimakasih}

Penulis mengucapkan terima kasih kepada Lembaga Penelitian Universitas Riau atas pembiayaan penelitian ini dan kepada Rio, alumni Program D3 Teknik Listrik Universitas Riau atas pengujian fungsional peralatan di lapangan.

\section{Daftar Pustaka}

[1] M. Goldstein, Carbon Monoxide Poisoning. Journal of Emergency Nursing, 2008, Vol. 34, No. 6, pp.538-542.

[2] A.K. Persily, Y. Wang, B. Polidoro and S.J. Emmerich, Residential Carbon Monoxide Exposure due to Indoor Generator Operation: Effects of Source Location and Emission Rate, NIST Technical Note 1782, National Institute of Standards and Technology, 2013.

[3] T.J. Ryan and K.J. Arnold, Residential Carbon Monoxide Detector Failure Rates in the United States, American Journal of Public Health, Vol.101 No. 10, 2011.

[4] S.J. Emmerich, A.K. Persily and L. Wang, Modeling and Measuring the Effects of Portable Gasoline Powered Generator Exhaust on Indoor Carbon Monoxide Level, NIST Technical Note 1781, 2013.
[5] J. Buyer, Technology Demonstration of a Prototype Low CO Emission Portable Generator, US Consumer Product Safety Commision, 2012.

[6] http://www.republika.co.id/berita/nasional/umum/1 4/02/12/n0ufla-polisi-selidiki-korban-keracunangas-dari-mesin-genset.

[7] http://news.detik.com/berita/2499874/kematian-5orang-di-klinik-rawalumbu-karena-keracunan-gaskarbon-monoksida.

[8] A.U. Adoghe and I.A. Odigwe, Remote Monitor and Controller System for Power Generator, Pasific Journal of Science and Technology, Vol.9 No.2, 2008, pp.344-350.

[9] S.W. Sidehabi dan S.N. Jabir, Pengontrolan Genset Jarak Jauh Melalui Website Berbasis Mikrokontroler Arduino MEGA 2560-16AU, Prosiding Seminar Nasional ReTII ke-9, 2014.

[10] S. Boopathi, M. Jagadeeshraja, L. Manivannan and M. Dhanasu, GSM Based Generator Monitoring System for Steel Melting Shop, International Journal of $\mathrm{u}$ - and e-Service, Science and Technology, Vol.8, No.2, 2015, pp.313-320.

[11] Wireless Remote Start Generators, http://www.ebay.com/bhp/wireless-remote-startgenerator.

[12] www.pcmag.com, Encyclopedia: Definition of ISM Band.

[13] Holtek Semiconductor, HT12A/HT12E 212 Series of Encoders, April 2000.

[14] Sunrom Technologies, $433 \mathrm{MHz}$ RF Transmitter STT-433, September 2007.

[15] Sunrom Technologies, $433 \mathrm{MHz}$ RF Receiver STR433, September 2007.

[16] Holtek Semiconductor, HT12D/HT12F 212 Series of Decoders, November 2002.

[17] Atmel Corporation, Range Calculation for 300 $\mathrm{MHz}$ to $1000 \mathrm{MHz}$ Communication Systems, Application Note, 2015.

[18]R.L. Freeman, Radio System Design for Telecommunications, 3rd edition John Wiley \& Sons, 2007, pp.1-33.

[19] Maxim Integrated Products, Path Loss in Remote Keyless Entry Systems, Application Note 3945, 2006.

[20] R. Rudd, K. Craig, M. Ganley and R. Hartless, Building Materials and Propagation : OFCOM Final Report, Aegis System Limited, September 2014. 